DOI 10.26886/2414-634X.6(25)2018.13

UDC: 792 / 796.4

\title{
ACROBATICAL-VOLTAGE IN THE SYSTEM OF HIGHER EDUCATION: AN ANALYSIS OF THE SCENIC METHOD FOR PRACTICAL STUDY OF THE INCREASED COMPLEXITY FOR THE SPECIALIZATION "CIRCUS ACROBATICS"
}

\section{Dmitry Orel}

Kyiv Municipal Academy of Variety and Circus Art, Kyiv, Ukraine

In the article the definitions of the acrobatic genre, in particular the peculiarities of acrobatical-voltage, are considered. An analysis of the scenic method in practice for studying acrobatic exercises of increased complexity is given. Examples are given of special jumps, as well as voluntarily acrobatics in the genre "Circus acrobatics", in the context of artistic education of the circus. Also, the historical information of the Kiev school of circus acrobatics is briefly indicated. Ontological characteristics of certain terms for acrobatics are given, to understand their specific features.

Key words: circus art, circus genre, acrobatics, acrobatical-voltage, circus acrobatics, scenic method, Kyiv municipal academy of Circus art.

Дмитрий Орёл, Акробатический вольтиж в системы высшего образования: анализ сценического метода в практическом изучении повышенной сложности для специализации «Цирковая акробатика» / Киевская муниципальная академия эстрадного и циркового искусств, Украина, Киев

В статье рассмотрены дефиниции акробатического жанра, в частности особенности вольтижной акробатики. Дан анализ сценического метода на практике для изучения акробатических упражнений повышенной сложности. Приведены примеры специальных прыжков, а также вольтижной акробатики по жанру "Цирковая акробатика», в контексте художественного образования циркового направления. Также, кратко указаны исторические сведения Киевской школы цирковой акробатики. Даны онтологические характеристики отдельных терминов по акробатике, для понимания их специфики.

Ключевые слова: цирковое искусство, цирковой жанр, акробатика, акробатический вольтиж, цирковая акробатика, сценический метод, Київська муніципальна академія естрадного та циркового мистецтва.

\section{Formulation of the problem}

To understand the peculiarities of poorly studied formal technical methods, as well as the stage method in the Kiev School of Circus acrobatics, in the jumps of high-level jumps, as well as acrobatic voltages. 


\section{The purpose of the article}

Determine the features of the technology of performing acrobatic jumps of increased complexity, as well as find out the priory acrobatic voltages.

\section{Analysis of research}

Such studies in the field of circus criticism as well as acrobatic pedagogy were conducted by such professional pedagogues and researchers as Belokhvostov Boris [2], Kashevarov Vladimir, Kozhevnikov Sergei [4], Sokolov Eugene. Their research concerned art methodology for acrobatics, scenic and technical props for circus acrobats on the arena and under the dome, as well as the processes of aesthetic realization of the artistic image in circus criticism.

\section{Statement of the main material}

For starters, let's look at some concepts that require more attention for further understanding of specific terminology in acrobatics.

Acrobatics is a circus and sports genre. By varieties acrobatics is classified - parterre, solo, steam, group; acrobats-riders; grotesque; acrobatics jump, static, tempo, cascade, humeral; acrobatics with a trampoline; acrobatics with flip-flops; acrobatics with a springboard; acrobatics voltige (acrobatic voltige) acrobatics power, acrobatics (air) on the frame - in the basis of which special exercises, different in nature and degree of complexity, demonstrate the physical perfection of man.

Acrobatic voltige - a kind of acrobatics, based on methods of throwing and tipping the upper lower or lower, is carried out only by muscular-tempo efforts without the use of throwing devices (formerly called "hand-voltige" from hand-arm)

For starters, a small historical reference, which is directly related to the problems of this article.

Yuri Zbaraschenko - acrobat, head of the number «Acrobatsjumpers». Teacher in acrobatics (jumping, voltige) of the Kiev State School of Diversity and Circus Art in 1980-2000s. Master of the course of acrobats-voltigers led by Gregory Stepanov. Outstanding tricks in a room with six acrobats voltigers, the 1993 release - "Half flick-flak" (the transition from one grid to another), "Double pirouette (the one that flies from above) - Courbet (the one that flies from below)", "Triple saulto from the grid into the grid", performer Dmitry Orel (Senior Lecturer Kyiv State Variety and Circus Art School p. 131-133..

Practical classes on the discipline "Specialization in the genre Circus acrobatics" by the scenic method Dmitry Orel. Illustrative lesson on acrobatic elements of increased complexity as the final stage of studying the course of the academic discipline "Specialization in genres - Circus acrobatics" [5, p. - 65-72.].

\section{Jumping acrobatics} elements.

1. Rondad-flic-flac - Grouped saulto, combination with three 


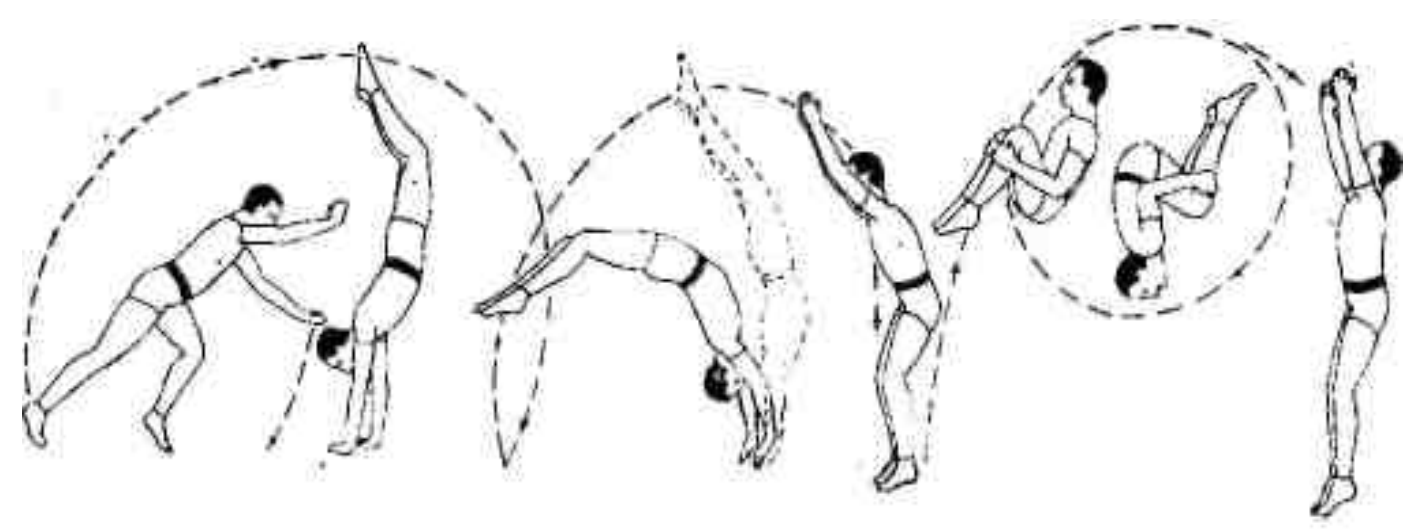

Puc. 21

\section{Execution:}

Rondad. With a run-up, having made a waltzet set with the left foot, the student tilts the body and arms down while simultaneously carrying out straight arms in front of him. Placing his hands on the ground, the student, with a jerk of his left foot and a stroke of his right, goes to the handstand; moreover, the left hand becomes on the line of the right leg, and the right hand is slightly brought to the left and placed on the line of the left leg.

Hands are placed across the width of the shoulders. With access to the handstand, the left leg joins the right leg and the body turns $180^{\circ}$.

Flic-flac. Initial position. Standing, legs slightly apart, legs parallel, straight, straight, unstressed hands lowered, but to the seams, palm trees are directed back. The student does a shallow squat, while tilting the straight body back and extending the arms. At the moment of loss of balance, the student makes a strong wave from the bottom up through his head with his arms raised. When the arms in their movement reach the head, the head leans back. Waving arms, legs, straightening, pushing off from the floor and joining together, the body bends in the lower back, and the student approaches straight arms on the floor (arms across shoulders width).

With the arrival of hands on the floor, the body continues the rotational motion by inertia, obtained from waving hands and kicking, as if forming an arc.

Pushing straight arms away from the floor, the student gets to his feet, raising his arms.

Grouped saulto. After the flick-flak, the legs are placed on the floor a little further than with the flick-flak at a pace. In this exercise, it is required that the flic-flak give inertia for the execution of the following back saulto, that is, abruptly carrying out the curbet, pushing off with straight legs, the student must, if possible, gain the greatest height and at the highest point of take-off be grouped for the rear saulto.

Common errors encountered during execution individual acrobatic elements [2, p. 145]. 
Rondad.

1. Performing a waltzed not on the same line (crossing the legs).

2. Premature shoulder rotation.

3. Leap on hands.

4. Simultaneous hands setting.

5. Hose in the back when passing through the handstand.

6 . Landing is not on the run line.

7. After performing a rebound with a deflection.

Flick-flak.

1. Premature tilt of the head and body back.

2. Mach bent arms are not behind his head back, and up.

3. Weak and late kick with legs.

4. During a push with the legs, the knees go forward.

5. Shoulders go forward when setting hands.

6. Weak push hands.

\section{Rondad Saulto-Blanche.}

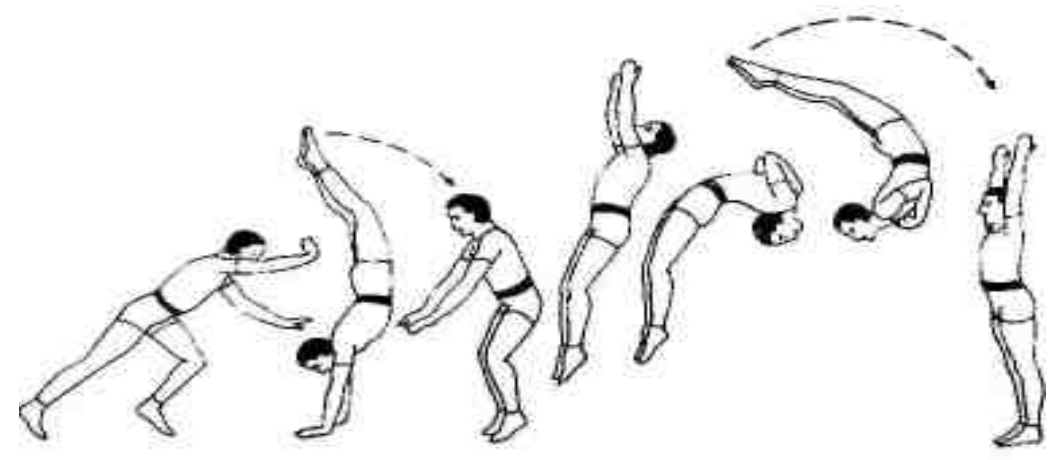

Puc. 29

Back saulto-blanche performed with mileage, from rondad; With this coup, it is also useful to fill out acrobatic combinations consisting of click flick in pace.

Execution:

A student, having made a run up run, pushes his straight legs off the floor, slightly pointing the body backwards. Taking off, the student raises his hands up, deflects his head back and begins to do somersaults: bends his elbows and presses them to his chest, opens his chest and bends strongly in the lower back.

Pulling back saulto, the student takes his hands off his chest and comes to the floor with his hands up.

\section{Acrobat-voltage}

1. First half of the courbette from the feet of a partner. 


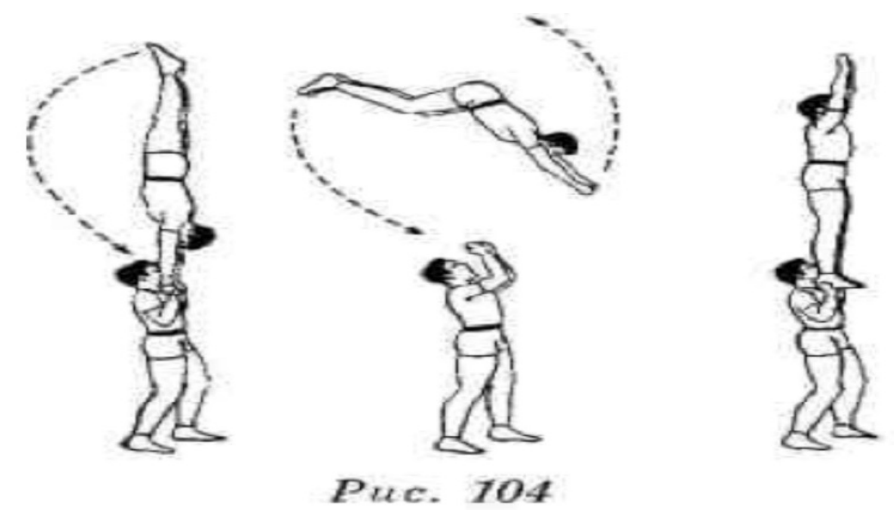

Initial position. Upper is standing with feet in hands, pressed to the chest of the lower hands. The body of the upper straight line without any bend in the lower back, he keeps his head straight, his legs straight, his straight arms raised above his palms forward and turned off at the shoulders.

Execution. The bottom one makes the tempo and throws the top up; the top one pushes with his feet and, tearing off the lower arms that throw him up, with a wave of his hands from top to bottom sharply bends the body forward, lifts it, makes the first half of the curbet and goes to the handstand. The upper one does not look for lower arms, but directs straight arms across the width of the shoulders and sharply straightens the legs, sending them up to the rack. The bottom, throwing up the top in front of him, leaves his hands raised and takes the hands of the top. The lower one softens the upper course, bending his arms, pressing them to the chest and at the same time doing a shallow squat. There is a fixation of the rack in the hands. This position is the starting point for the next exercise [4, p. 51-52].

Notes.

1. When performing this exercise, special attention should be paid to the correct position of the lower hands as in the original position (the feet of the upper on the lower hands should be in a strictly horizontal position, the heels should never be omitted) and at the exit of the top to the handstand (the hands of the bottom should not fall).

2. Both partners must do the pace at the same time.

3. The first half of the curbet is much more complicated than the second, so you should start training from the second half.

2. Half Flick-Flak (flipping back in the partner's hands).

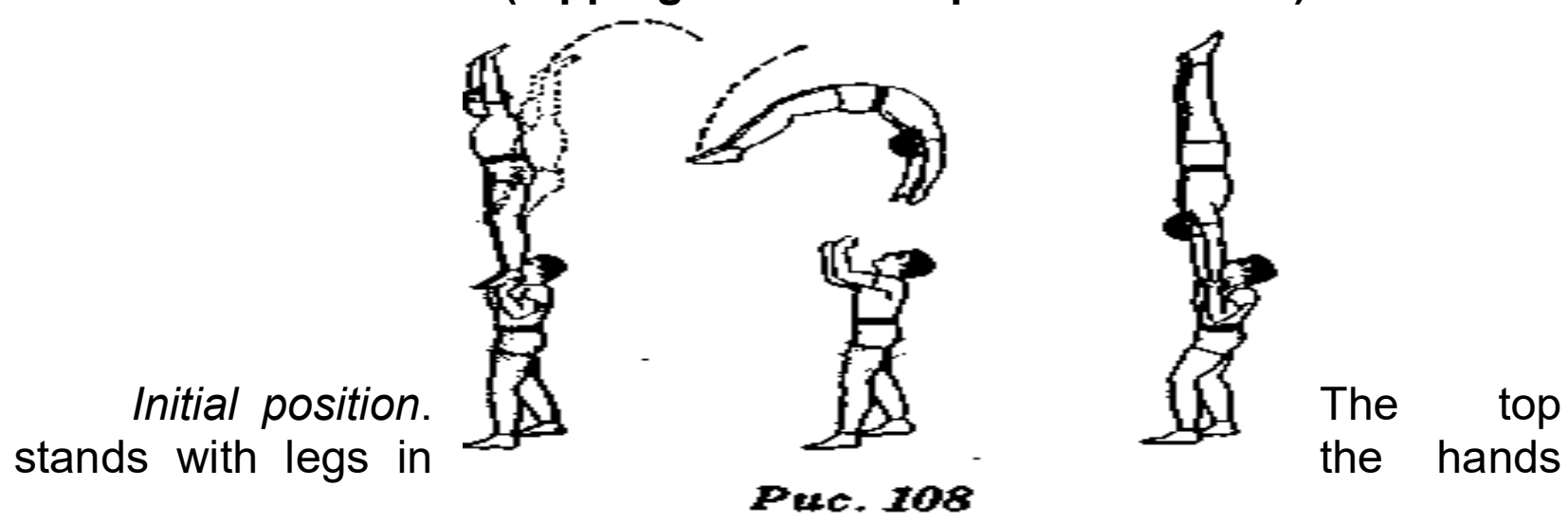


of bent lower arms. The body is straight, the head is.

Execution. At the same time with the lower tempo and the downward movement of the hands, the upper layer makes a shallow squat, slightly tilting the straight body back, without changing the position of the head and hands. Simultaneously with the movement of the lower arms (with his throw), the upper one pushes away from the arms, straightens the legs, turns abruptly, reverses, and approaches the position of the handstand. Bottom, making a tempo, throws the upper arms with his hands, leaves his arms raised and catches the upper hand after his revolution with his hands. The lower one softens his approach to the handstand, crouching, at the same time bending his arms and pressing them against the pile. The top one, having come to the stand in the bottom one, straightened up and joining the legs, adopts the correct position of the handstand [3, p. 171].

\section{Conclusions}

Thus, all of the above indicates that the clarity of acrobat-voltage is important, from the correct execution of complex jumps, the systematic and accurate implementation of all the nuances and formal technical characteristics. A clear analysis and a correct theoretical basis create the possibility for an accurate implementation on the stage method in practice. It is also important for vocational training on the scenic method in higher education systems - bachelor and master in specialty "Circus acrobatics". Acrobat-voltage today is one of the most interesting types of circus acrobatics, which requires detailed study and teaching of young circus performers in our country.

\section{Literature:}

1. Акробатика: программа для училищ циркового и эстрадного искусства по специальности № 2109 «Цирковое искусство» (отделение циркових жанров). - М. : ВМУЗИК, 1980. - 36 с.

2. Белохвостов Б. Н. Вольтижная акробатика / Б. Н. Белохвостов. М.: ЛКИ 2012. - 304 c.

3. Запашный В.М. Вольтижная акробатика / В.М. Запашный. М. Искусство, 1961. - $131 \mathrm{c}$.

4. Кожевников С. В. Акробатика: учеб. пособие для училищ циркового искусства / С. В. Кожевников. - М.: Искусство, 1984. Изд. 3-е. доп. 222 c. : puc.

5. Orel Dmytriy. Masterly technique in the genre "Circus acrobatics" by the author's stage method in the Kiev Municipal Academy of Variety and Circus Arts // Paradigme of knowledge. - Section "Art". - Muscat, Oman: Center for international cooperation TK "Meganom", LLC. - 2018. - № 4 (30). - P. $-65-72$.

6. Sharykov Denys. Neoclassical choreography in the context of circus genres: features of dance and plastics in the circus // Paradigme of 
knowledge. - Section "Art". - Muscat, Oman: Center for international cooperation TK "Meganom", LLC. - 2017. - № 3 (23). - P. 138-143.

\section{References:}

1. Acrobatic: a program for circus and variety art schools on specialty No. 2109 "Circus Art" (department of circus genres). - M.: VMUZIK, 1980. - 36 p.

2. Belokhvostov Boris. Voltige acrobatics / Boris Belokhvostov. - M.: LKI 2012. $-304 p$.

3. Zapashnyj V. Voltige acrobatics / V. Zapashnyj. - M.: Iskusstvo, 1961. $131 p$.

4. Кожевников Сергей. Acrobatics: a textbook. manual for schools of circus art / C. Кожевников. - M.: Iskusstvo, 1984. Izd. 3-e. dop. - 222 p.: ris.

5. Orel Dmytriy. Masterly technique in the genre "Circus acrobatics" by the author's stage method in the Kiev Municipal Academy of Variety and Circus Arts // Paradigme of knowledge. - Section "Art". - Muscat, Oman: Center for international cooperation TK "Meganom", LLC. - 2018. - № 4 (30). - P. - 65-72.

6. Sharykov Denys. Neoclassical choreography in the context of circus genres: features of dance and plastics in the circus // Paradigme of knowledge. - Section "Art". - Muscat, Oman: Center for international cooperation TK "Meganom", LLC. - 2017. - № 3 (23). - P. 138-143. 